\title{
$>0$ amor que não ousa dizer seu nome: notações homoculturais em 0 Retrato de Dorian Gray, de Oscar Wilde
}

\author{
> The love that dare not speak its name: Homocultural notations in The \\ Portrait of Dorian Gray, by Oscar Wilde
}

\section{por Leandro Souza Borges Silva}

Mestrando pelo Programa de Pós-Graduação em Letras: Linguagens e Representações (PPGL), da Universidade Estadual de Santa Cruz (UESC). Graduado em Letras pela mesma instituição. E-mail: leandroborgees@hotmail.com. ORCID: 0000-0003-1856-0367.

\section{Resumo}

Objetiva-se evidenciar as notações homoculturais em O Retrato de Dorian Gray (1890), de Oscar Wilde. Assim, ao intentar destacar a homoafetividade presente no romance, são ancorados conceitos a respeito do "espaço biográfico" (ARFUCH, 2010), bem como as nuances históricas da vida do autor, delineadas por Pires (2005) e Schiffer (2011), além dos pressupostos sobre homocultura e homoafetividade, fundamentados em Foucault (2010) e Lugarinho (2004). Em perspectiva bibliográfica, nota-se que os aspectos homoculturais no romance se estabelecem nos trechos em que estão presentes nuances significativas de afetividade homossexual. Nesse sentido, esta abordagem pretende-se não somente enquanto uma discussão teórico-analítica, mas também como um constructo socialmente engajado, enviesando abordagens literárias dissidentes de perspectivas heteronormativas.

Palavras-chave: Dorian Gray. Oscar Wilde. Homoafetividade. Homocultura.

\begin{abstract}
The objective is to highlight homocultural notations in The Portrait of Dorian Gray (1890), by Oscar Wilde. Thus, with the intention of highlight the homoaffectivity presented in the novel, concepts about the "biographical space" (ARFUCH, 2010) are anchored, as well as the historical nuances of the author's life, outlined by Pires (2005) and Schiffer (2011), besides the assumptions about homoculture and homoaffectivity, based on Foucault (2010) and Lugarinho (2004). It is noticed that the homocultural aspects in the novel are established in the excerpts in which significant homosexual affectivity nuances are present. In this sense, this approach is intended not only as a theoretical-analytical discussion, but also as a socially engaged construct, biasing dissident literary approaches of heteronormative perspectives.
\end{abstract}

Keywords: Dorian Gray. Oscar Wilde. Homoaffectivity. Homoculture. 


\section{Considerações iniciais}

Esta discussão se viabiliza por se efetivar enquanto material analítico, teórico-reflexivo e científico que se insere no arcabouço dos estudos literários contemporâneos que protagonizam e resgatam a voz emancipatória de camadas marginalizadas. Tendo isso em vista, esta análise especifica-se ao legitimar e problematizar a homossexualidade enquanto instância expressiva da sociedade que é, no entanto, submetida a variados processos de coação, opressão, discriminação e silenciamento. Nessa perspectiva, para além de uma análise literária, esta abordagem se configura como um constructo teórico-críticoanalítico que problematiza questões referentes à homocultura e, portanto, se efetiva enquanto análise literária socialmente engajada.

É nessa perspectiva que, objetivando analisar as notações homoculturais presentes em 0 Retrato de Dorian $\mathrm{Gray}^{1}$, esta análise resgata o protagonismo e as formas de expressão dos homossexuais que foram historicamente suprimidas pelo poderio patriarcal, machista e androcêntrico. É nessa empreitada que Oscar Wilde adquire importância sem a qual esta pesquisa não seria possível, pois o escritor é considerado um dos precursores do movimento gay pelo mundo. No auge de sua carreira, Oscar Wilde envolveu-se num escândalo ao se relacionar com o jovem Lord Alfred Douglas, sendo indiciado e condenado em 27 de maio de 1895, acusado de imoralidade - na época, a homossexualidade era considerada crime -, tendo de pagar a pena de dois anos de prisão com trabalhos forçados.

\footnotetext{
${ }^{1}$ Tendo sua primeira publicação datada em 1890, a versão analisada no presente texto é a edição traduzida de 1971, da coleção Grandes da Literatura Moderna, da Editorial Verbo.
} 
Ao ser considerado como um dos mais simbólicos porta-vozes da causa gay, a figura e obra de Oscar Wilde colaboram para o protagonismo dos homossexuais e, portanto, permitem aprofundar problematizações acerca da homocultura. Entende-se por homocultura os modos e maneiras de ser, de agir e lidar com o mundo que são próprias de sujeitos que expressam sua transgressão de gênero. Nessa perspectiva, ao tematizar a expressão de novas formas culturais que não se coadunam com as relações tradicionais, Foucault afirma que "não se trata de integrar essa pequena prática bizarra, que consiste em fazer amor com alguém do mesmo sexo, nos campos culturais preexistentes; trata-se de criar formas culturais"2.

Aspecto pungente em $O$ Retrato de Dorian Gray, são muitas as abordagens que relacionam o romance com a homocultura, ou que tematizam a homossexualidade dos personagens, ou a do autor. O emprego dessas relações é necessário, a fim de combater o preconceito e o receio cego de muitos estudiosos a respeito dos estudos relativos à homossexualidade, seja na literatura ou em outras áreas. Portanto, trata-se de reforçar que, em se tratando de um romance que critica a sociedade aristocrática vitoriana de forma arrebatadora, o livro se constitui como um material suscetível a diversas abordagens, dentre as quais a homocultural.

Muitos estudos analisam a crítica social presente em O Retrato de Dorian Gray, outros estudos analisam a vinculação do romance ao movimento esteticista criado pelo escritor, demais estudos analisam a voz do autor presente na

\footnotetext{
${ }^{2}$ Michel Foucault, "O triunfo social do prazer sexual: uma conversação com Michel Foucault", 2010, p. 119-120.
} 
narrativa, bem como outras análises averiguam também a recepção que o romance teve na época. No entanto, cabe, na presente análise, ressaltar os estudos que enfocam a homossexualidade do escritor, ou o teor homossexual de seu principal romance, contrapondo-se às perspectivas que cercam esse tema de tabu e censura.

Assim, constituindo-se de uma abordagem que não está desvinculada de sua conjuntura social, política e histórica, o presente estudo pretende tecer problematizações acerca das camadas marginalizadas da sociedade no âmbito científico-acadêmico. Nesse viés, ao intentar analisar como se estabelecem os aspectos homoculturais no romance de Oscar Wilde, esta discussão protagoniza os homossexuais e possibilita processos de identificação, legitimação e pertença desses sujeitos até então relegados às instâncias inexpressivas, mas que adquirem agora, cada vez mais, direito e poder de enunciação.

\section{Recepção da obra}

O romance $O$ Retrato de Dorian Gray, de Oscar Wilde, conta a história de um jovem aristocrata cuja beleza é a maior característica. Dorian Gray, personagem que dá título ao romance, é apresentado ao leitor primeiramente como um sujeito tímido e ingênuo que não se apercebe da própria beleza. Aos poucos, sob influência de outro personagem, Lord Henry Wotton, Dorian sofre mutações negativas tanto na sua vida quanto no caráter, mudanças depreciativas que não se operam e nem se percebem na aparência física, mas sim em seu fabuloso retrato, pintado pelo amigo devoto Basílio Hallward, também chamado de Basil. 
A narrativa do romance começa num estúdio de arte, onde se encontra Lord Henry, que fica fascinado ao ver o retrato de um jovem cuja beleza lhe é extraordinária; ao perguntar a Basílio, pintor do retrato, sobre a identidade do jovem, nota-se certa afetividade do artista em relação à pintura; afetividade essa que também se instaura em Lord Henry. Ambos os personagens, igualmente interessados/embasbacados pelo retrato, enunciam a relação com ele de maneiras próprias, enquanto para Basílio sua própria pintura lhe inspira devoção - o quadro não representa apenas a beleza de Dorian, mas reflete também a essência artística e, portanto, íntima de Basílio -, para Lord Henry a pintura lhe inspira fascinação, curiosidade e interesse.

Neste mesmo cenário, o alvo de admiração e interesse surge em pessoa no estúdio, pois Dorian Gray, além de modelo para o retrato de Basil, também é amigo dele. Lord Henry aproveita-se da oportunidade para conhecer Dorian e, ali mesmo, seduz o jovem com seus ideais filosóficos hedonistas, além de enaltecer sua beleza e comentar sobre a fugacidade da vida. Nesse encontro, o jovem sentese seduzido pelo mundo de prazeres de que Lord Henry lhe fala, e lamenta a perenidade de sua beleza, de modo que ao ver a própria imagem no quadro, exalta as preces proféticas que viriam a ser seu pesadelo:

Como é triste! - murmurou Dorian Gray, cujos olhos se não tinham despregado ainda do retrato. - Como é triste!! Vou tornar-me velho, horrível, disforme. Essa pintura, ao contrário, permanecerá sempre jovem. Não será nunca mais velha que neste próprio dia de Junho ... Ah, quem me dera que fosse o contrário! Quem me dera ser eu a permanecer sempre jovem e o quadro a tornar-se velho! Daria tudo, por isso! Sim, nada existe no mundo que eu não desse! Daria a minha própria alma! ${ }^{3}$

\footnotetext{
${ }^{3}$ Oscar Wilde, O Retrato de Dorian Gray, 1971 (1890), p. 32.
} 
Nesse trecho do romance, Dorian Gray pronuncia as palavras com tanta paixão e sentimento que esse desejo fantástico e irreal é concedido, pois, sem perceber, ele abre mão da alma em troca da eterna beleza. A partir desse momento, será o retrato que refletirá a idade e a degradação moral de Dorian. Após esses acontecimentos, o enredo se desenvolverá de forma que o retrato envelhece e se decompõe conforme Dorian Gray comete atos pérfidos que corrompem seu caráter, sua moral e integridade, tornando-o um homem que, apesar da beleza estonteante, carrega em si muitos pecados e crimes contra a essência humana. Desse modo, no romance, "o pecado é uma coisa que se inscreve no rosto de uma pessoa [...] Se um homem corrompido tem um vício, mostra-o nas linhas da boca, nas pálpebras pesadas, e até no formato das mãos" ${ }^{4}$. No caso do protagonista, isso não ocorre, pois os pecados de Dorian não se percebem na aparência, mas apenas em seu retrato.

Logo, ao degradar-se em atos de desvio moral e de conduta, a imagem do protagonista se deteriora; é por esse motivo que o retrato de Dorian envelhece e toma formas monstruosas, sendo que os demais personagens não acreditam na decadência moral do jovem, haja vista seus traços físicos tão delicados e perfeitos. Nesse romance, ao pôr em cena um personagem de aparência bela e intocada que, no entanto, é destituído de qualquer característica nobre e singela, Oscar Wilde tece duras críticas aos ideais de uma sociedade superficial e hipócrita.

Essas críticas estão patentes em toda narrativa, demonstrando também outros aspectos que condizem com a atitude subversiva de Wilde: a exemplo das notações de afetividade homossexual presente na relação entre os personagens,

\footnotetext{
${ }^{4}$ Ibidem, p. 149
} 
mais especificamente o relacionamento que Basil e Lord Henry desenvolvem com Dorian Gray. Consequentemente, "esta obra foi severamente criticada e considerada envenenadora de costumes por apresentar claramente o tema do homossexualismo" ${ }^{5}$.

O Retrato de Dorian Gray foi publicado pela primeira vez na revista mensal Lippincott's, em julho de 1890, causando excessivas críticas, opiniões aversivas e ataques ao autor, principalmente pelo que chamavam de "imoralidade" do romance, claramente referindo-se às relações homossexuais entre os personagens. Além disso, as "três primeiras críticas publicadas são as mais agressivas e desaprovam, principalmente, que o assunto tratado seja a corrupção da alma e não um exemplo de moralidade, além de acusarem a obra de não ser 'verdadeira'"6. Nesse aspecto, claramente negando-se a seguir premissas da mimeses aristotélica - mesmo que Aristóteles tenha se referido à tragédia e não ao romance - Wilde criou uma narrativa que não enaltecia as virtudes de outrem, mas sim os vícios, subvertendo, portanto, a função que supunha a arte moralizante, aquela que deve propagar os ideais morais, éticos e privilegiar ensinamentos para a vida e para o bem-viver.

De fato, o autor intenta propagar certos valores, mas o faz de maneira aquém dos padrões estabelecidos na época, pois, ao invés de enaltecer os bons costumes para, em detrimento, criticar os maus hábitos, o escritor irlandês privilegia tematizar os maus hábitos para falar daquilo que muitos fingem praticar: os bons costumes. As muitas críticas atribuídas ao romance não

\footnotetext{
${ }^{5}$ Eliane Cristine Raab Pires, Oscar Wilde: A tragicidade da vida de um escritor, 2005, p. 17.

${ }^{6}$ Tânia Toffoli, O Retrato de Dorian Gray: um romance em três tempos - Circulação entre Inglaterra e Brasil, 2013, p. 21.
} 
deixariam de se referir também ao próprio Oscar Wilde, pois muitos acreditavam que o mesmo era devoto da filosofia hedonista tão endossada no livro:

Como a sociedade britânica vivia um momento de homofobia nesse fim de século, principalmente em razão de alguns escândalos sexuais que envolviam aristocratas e militares ingleses com jovens garotos de programa em um bordel, muitos jornalistas escreveram críticas bastante negativas sobre a imoralidade contida no romance. ${ }^{7}$

Tal imoralidade contida no romance foi relacionada a Oscar Wilde, o que suscitou comentários e conjecturas em relação a sua vida, hábitos, pensamentos e inflexões. Já nesta época, Wilde era uma figura importante no cenário literário e social, se efetivando enquanto figura pública renomada, sendo alvo de admiração e curiosidade de muitos, de forma que

a popularidade de que gozava o escritor contribuía para esse tipo de associação, já que era uma personalidade notória por suas provocações, muito frequentemente reproduzidas nas falas de seus personagens tanto no teatro quanto no romance. ${ }^{8}$

Para compreender as críticas e ataques à obra de Wilde, bem como as relações que fizeram entre sua vida e obra, é preciso entender aspectos importantes de sua biografia, além de tecer conceituações teóricas que aproximam as fronteiras existentes entre autor/narrador e autor/obra,

\footnotetext{
${ }^{7}$ Rebeca Pinheiro Queluz e Andressa Cristine Marçal da Silva, "Oscar Wilde Revisitado", 2015, p. 171-172.

${ }^{8}$ Tânia Toffoli, Op. Cit., 2013, p. 28.
} 
possibilitando discutir a polêmica que o relacionamento entre Oscar Wilde e Lord Alfred Douglas suscitou na sociedade daquele período.

\section{Oscar Wilde e Dorian Gray: liames entre realidade e ficção}

Oscar Fingal O'Flahertie Wills Wilde nasceu em Dublin, Irlanda, em 16 de outubro de 1854, filho do Dr. William Robert Wills Wilde e da escritora Jane Frances Elgee. Oscar cresceu num ambiente culto e privilegiado, sendo iniciado no mundo erudito e intelectual desde cedo ${ }^{9}$. Durante a vida estudantil e acadêmica, destacou-se com prêmios e menções honrosas, dentre os quais o Prêmio Newdigate de Poesia, conquistado com a declamação de seu poema intitulado "Ravenna", no teatro da Universidade de Oxford em 26 de junho de 1878. Já mais velho, Oscar encontra-se no auge da carreira literária, sendo autor de peças de teatro renomadas, bem como escritor do polêmico e estrondoso romance $O$ Retrato de Dorian Gray. Sempre conhecido pelas vestimentas peculiares e pelo gosto diferenciado, “destacou-se não só pela inteligência, mas pelos cabelos compridos, pelas excentricidades das atitudes e das roupas"10, estabelecendo-se como personalidade não só excêntrica, mas também desafiadora. É dessa maneira que Oscar Wilde apresentava-se ao público

[...] de forma extravagante, com cabelos encaracolados, casaco de veludo, calções, camisa larga de colarinho baixo. As suas gravatas eram de cores fortes e vistosas. Na lapela colocava um cravo; outras vezes, levava na mão um girassol ou um lírio. Foi um dandy receptivo a todos os estímulos provenientes da vanguarda cultural europeia em geral. Seguia a francesa

\footnotetext{
${ }^{9}$ Daniel Salvatore Schiffer, Oscar Wilde: biografia, 2011.

${ }^{10}$ Eliane Cristine Raab Pires, Op. Cit., 2005, p. 14.
} 
em particular. Foi, todavia, diferente e o único que levou realmente a sério o Dandismo. A sua maneira de vestir exprimia empenho total, e o cravo verde, com conotação decorativa, tinha sobretudo um carácter confessional. ${ }^{11}$

Essas características de uma personalidade tão singular não seriam, no entanto, as que causariam polêmica em sua vida. Em Oxford, após conhecer Robert Ross em 1886, Oscar Wilde principia relações homossexuais. Com o tempo, já escritor talentoso e personalidade pública destacada, Wilde depois envolveu-se amorosamente com o jovem Lord Alfred Douglas, fato que repercutiu de forma avassaladora na sociedade da época. Desses fatos que ligam o escritor à sua homossexualidade, há o julgamento que ocorreu em 1895, processo no qual o escritor foi indiciado e condenado por sodomia em 27 de maio do mesmo ano.

O relacionamento com Lord Alfred Douglas culminou no supracitado processo judicial encabeçado pelo pai do jovem aristocrata, em que foram revelados casos que comprovavam os envolvimentos homossexuais do escritor. A partir desses fatos, muitos consideram que "a maior tragédia da vida de Oscar Wilde foi sua fortíssima paixão pelo jovem Lord Alfred Douglas, intimamente chamado Bosie $[\ldots]^{12}$.

Dessa forma, no que se refere a recepção que O Retrato de Dorian Gray teve quando foi publicado, podemos compreender as conexões, ligamentos e relações que o público fez entre o romance e a vida de Oscar Wilde, pois o escritor estava no auge quando publicou o romance, bem como foi nesse período que ele

\footnotetext{
${ }^{11}$ Ibidem, p. 14-15.

${ }^{12}$ Ivan Bilheiro, Gênio na vida, talentoso na arte: Uma visão da biografia de Oscar Wilde, 2013, p. 14.
} 
conheceu o jovem Lord Alfred. Como se sabe, o notório e polêmico romance literário de Wilde seria utilizado contra ele próprio em seu julgamento. Essa ocorrência suscita, portanto, reflexões a respeito das fronteiras perenes que há entre realidade e ficção, bem como possíveis acepções literárias que teorizam as proximidades dessas instâncias díspares e também próximas.

Paul de Man, filósofo belga, afirma que, em último caso, todo texto seria autobiográfico. ${ }^{13}$ Leonor Arfuch, em perspectiva crítica, comenta que são muitos os gêneros que integram o espaço biográfico, evidenciando uma multiplicidade de formas discursivas que, apesar de não apresentarem as mesmas estruturas tipológicas do gênero biográfico, evidenciam muitos aspectos concernentes a esse, caracterizando o espaço biográfico ${ }^{14}$. Nesse espaço, em que está inserido, inclusive, o gênero romanesco, nota-se presença de elementos relativos às narrativas do gênero biográfico tradicional, pois "elas contam, de diferentes modos, uma história ou experiência de vida. Inscrevem-se, assim, para além do gênero em questão [...]"15.

Pode-se inferir que tal pressuposto se confirma se forem consideradas as muitas correlações feitas entre vida e obra de inúmeros autores, tal qual é o caso da recepção que 0 Retrato de Dorian Gray teve na época, em que muitos acreditaram que Oscar Wilde poderia estar contando suas histórias e vivências em seu livro. A suposta indecência da narrativa não era criticada somente pelas nuances intratextuais, mas também extratextuais, mais especificamente em relação à vida privada desse escritor, "porque se acreditava estar relacionada à

\footnotetext{
${ }^{13}$ Paul de Man, Autobiografia como Des-figuração, 2012.

${ }^{14}$ Leonor Arfuch, O espaço biográfico: dilemas da subjetividade contemporânea, 2010.

${ }^{15}$ Ibidem, p. 111.
} 
vida íntima de Wilde, o que se agravaria, mais tarde, com o julgamento e sua prisão, em $1895^{\prime 16}$. Assim, a ligação que leitores e críticos fazem entre a vida e a obra de determinada personalidade já é conhecida e aceita por muitos. No entanto, o filósofo e teórico Mikhail Bakhtin, ao discutir a respeito das noções de autor e narrador, contribui de forma relevante para a necessária distinção entre essas duas instâncias. Ao citar o pensador russo, Cavalheiro reproduz as palavras do pensador que, primeiramente, considera o narrador enquanto instância presente somente na obra, e não fora dela, sendo

[...] a consciência que abrange a consciência e o mundo da personagem, que abrange e conclui essa consciência da personagem com elementos por princípio transgredientes a ela mesma e que, sendo imanentes, a tornariam falsa. ${ }^{17}$

Ao afirmar isso em Estética da criação verbal ${ }^{18}$, Bakhtin faz a distinção entre o autor enquanto pessoa e o autor enquanto figura implícita, presente apenas na obra. Essa distinção, teoricamente, toma forma com a ambivalência autor-pessoa e autor-criador, de modo que o primeiro se estabelece como pessoa empírica no mundo "físico" e "real", e o segundo se efetua apenas nas linhas intratextuais do discurso romanesco. O autor-criador, nesse sentido, se configura como um Outro necessário para a concretização do imaginário do texto, em que as concepções de Exotopia e Excedente de Visão tornam-se vieses para que o autor-pessoa possa tornar-se o Outro na configuração de sua obra. Portanto, o autor-pessoa,

\footnotetext{
${ }^{16}$ Tânia Toffoli, Op. Cit., 2013, p. 43.

${ }^{17}$ Juciane dos Santos Cavalheiro, "A concepção de autor em Bakhtin, Barthes e Foucault", 2008, p. 73.

${ }^{18}$ Mikhail Mikhailovich Bakhtin, Estética da criação verbal, 2003.
} 
enquanto elemento exterior na elaboração do discurso narrativo, constrói a figura do autor-criador - ou autor-narrador, como também é denominado -, que se efetiva como elemento interior da obra. Nesse sentido, Cavalheiro reproduz as palavras de Cristóvão Tezza e endossa que

é esse excedente de visão e conhecimento que dá ao autor-criador o princípio de acabamento ao objeto estético. Desse modo, a relação criadora é marcada pelo princípio da exotopia, isto é, o fato de uma consciência estar fora de outra, de uma consciência ver a outra como um todo acabado, o que ela não pode fazer consigo mesma. ${ }^{19}$

No entanto, apesar desta distinção e separação entre autor e narrador autor-pessoa e autor-criador, respectivamente - muitos indivíduos não levam em consideração as fronteiras entre essas duas instâncias, sendo que acreditam não haver nenhuma espécie de divisão ou separação entre esses âmbitos de expressão. No caso de Wilde, por exemplo, tanto a noção de autor quanto a de narrador foram vistas como se fossem ambas a mesma coisa:

A constante associação entre Wilde e seus personagens vem geralmente do interesse por sua vida particular, muitas vezes maior do que pela própria obra. No caso de Dorian Gray, o fato de ter sido utilizado como evidência durante o julgamento e diversos trechos terem sido lidos pelo advogado de acusação tornou o romance ainda mais atraente para aqueles interessados na biografa do autor. A popularidade de que gozava o escritor contribuiu para esse tipo de associação, já que era uma personalidade notória por suas provocações, muito frequentemente reproduzidas nas falas de seus personagens tanto no teatro quanto no romance. ${ }^{20}$

\footnotetext{
${ }^{19}$ Ibidem, p. 73-74.

${ }^{20}$ Tânia Toffoli, Op. Cit., 2013, p. 28.
} 
Além disso, o próprio Wilde agravou seu julgamento quando, numa carta, estabeleceu relações entre sua vida e obra, afirmando que "Basil é o que eu gostaria de ser, Lord Henry é o que o mundo pensa de mim e Dorian é o que eu era em outros tempos, talvez"21. Tais comentários, que posteriormente seriam utilizados, dentre outras provas, contra o escritor irlandês, propiciaram a interrelação entre a obra literária e sua vida, agravando, portanto, a sentença, havendo a consequente condenação a dois anos de prisão com trabalhos forçados, indiciado por homossexualidade.

\section{Notações homoculturais no romance}

Ao respeitar as distinções entre autor e narrador, vale ressaltar que discutir as notações homoculturais tanto na vida quanto na obra do supracitado escritor é extremamente relevante para tematizar a identidade homossexual e endossar a opressão a que muitos sujeitos que se desviaram da norma padrão, patriarcal e machista foram submetidos. Para o sistema judicial daquele período, que criminalizava o amor entre pessoas do mesmo sexo, estava evidente "que o culpado era Oscar Wilde, pela sua vida e também pela sua obra The Picture of Dorian Gray, que era o espelho do Decadentismo e que prenunciava a sua homossexualidade"22.

A respeito disso, Arfuch comenta que o gênero romanesco se constitui como um espaço de experimentações, em que a experiência e fatos biográficos

\footnotetext{
21 "Basil is what I'd like to be, Lord Henry is what the world thinks me and Dorian is what I was in other times perhaps." Ibidem, p. 28-29. Tradução minha.

${ }^{22}$ Eliane Cristine Raab Pires, Op. Cit., 2005, p. 25.
} 
podem estar presentes: “O romance é o território privilegiado para a experimentação, mesmo a mais perturbadora, na medida em que pode operar no marco de múltiplos 'contratos de veracidade', enquanto na margem se estreita no espaço biográfico, entre o factual e ficcional [...]"23. Tragicamente, as fronteiras entre fatos e ficção foram diluídas, aproximadas e cruzadas no julgamento de Oscar Wilde, levando-o à criminalização de um ato puramente inofensivo, porém incompreendido naquela época.

Atualmente, devido a reiteradas ações e políticas que resgatam a importância e os direitos dos sujeitos que foram subalternizados no decorrer da história por influências hegemônico-opressoras, é que vozes até então suprimidas conquistam enfim seu protagonismo. Assim, pode-se afirmar que os homossexuais, enquanto camada que foi segregada e violentada em diversas instâncias da sociedade, encontram enfim suporte não apenas político e judicial para sua legitimação, mas também suporte cultural, que se fundamenta por meio da homocultura, aqui entendida como “[...] uma cultura que inventa modalidades de relações, modos de vida, tipos de valores, formas de troca entre indivíduos que sejam realmente novas, que não sejam homogêneas nem se sobreponham às formas culturais gerais" ${ }^{24}$.

Assim, a homocultura se constitui enquanto um campo que possibilita abordagens afastadas da perspectiva canônica e excludente, tornando possível a abordagem de novas formas culturais. Nesse sentido, é importante ressaltar que

\footnotetext{
${ }^{23}$ Leonor Arfuch, Op. Cit., 2010, p. 126-127.

${ }^{24}$ Michel Foucault, Op. Cit., 2010, p. 122.
} 
os homossexuais singularizam-se não apenas por sua sexualidade mas, principalmente, pela afetividade. É esta que conduz grupos LGBT (lésbicas, gays, bissexuais, travestis e transexuais) a transformarem a orientação sexual em bandeira de militância política. É pelo direito de expressar a afetividade que são criadas ou reivindicadas leis de combate à homofobia ou relativas ao casamento e à adoção. E é a afetividade que está no cerne do teatro sobre o homoerotismo. ${ }^{25}$

Nesse sentido, compreendendo que sujeitos, tal qual Oscar Wilde em sua época, criam e demonstram novas maneiras de expressar a condição homossexual, pode-se entender que as expressões oriundas desses sujeitos, que assumem sua sexualidade e se subjetivam nos modos de ser e interagir com o mundo, criam e constroem um sistema complexo e rico de significações que se manifestam em diversas linguagens, materializando signos que se agregam ao imaginário social, inserindo no meio social inovadoras formas de interação interpessoal. Tais processos, ao passar por etapas de transformação, ressignificação e disseminação, adquirem características complexas que se entrelaçam aos saberes e tradições de determinada sociedade, evidenciando, portanto, novas formas culturais. Foucault, ainda na discussão sobre uma possível cultura gay, que atualmente já é consagrada em muitos meios sociais, afirma:

É então necessário lutar para dar espaço aos estilos de vida homossexual, às escolhas de vida em que as relações sexuais com pessoas do mesmo sexo sejam importantes. Não basta tolerar dentro de um modo de vida mais geral a possibilidade de se fazer amor com alguém do mesmo sexo, a título de componente ou de complemento. $O$ fato de fazer amor com alguém do mesmo sexo pode muito naturalmente acarretar toda uma série de

${ }^{25}$ Ferdinando Martins, "Do Arcaico ao Pós-moderno nas Representações do Gay no Teatro 
escolhas, toda uma série de outros valores e de opções para os quais não há possibilidades reais. ${ }^{26}$

Os estilos de vida homossexual a que Foucault se refere, ao ser relacionar às expressões dos sujeitos que enunciam sua sexualidade desviante das normas padrões e hegemônicas, já pode ser percebida em diversos âmbitos de nossa sociedade, pois a expressão gay, bem como outras, possuem caráter e configurações específicas que são adotadas por indivíduos constituídos sóciohistoricamente, evidenciando, pois, uma cultura sexualmente dissidente, a homocultura. No que diz respeito à literatura enquanto lócus de expressão da subjetividade homoafetiva, é evidente afirmar que

estamos diante de uma escrita procedida pelo corpo, lugar do desejo e, por conseguinte, da diferença. Uma escrita que se constrói pela corporalidade, dirige-se a seu leitor de forma direta e insistente, buscando um aparelhamento de sensorialidade que lhe dê condições de efetivar-se como discurso e, dessa maneira, encontrar a ressonância imediata. ${ }^{27}$

Sendo escrita em que o lugar do desejo está presente, em $O$ Retrato de Dorian Gray não se percebe, no entanto, uma escrita direta e insistente no que diz respeito à enunciação da subjetividade sexualmente dissidente, mas sim nuances, aspectos e fragmentos de homoafetividade em determinados trechos do romance. Apesar dos indícios referentes ao amor homossexual aparentemente tão tênues, o romance foi recebido pela sociedade daquela época de forma

\footnotetext{
${ }^{26}$ Michel Foucault, Op. Cit., 2010, p. 119-120.

${ }^{27}$ Mário Cesar Lugarinho, "Homocultura e literatura: de volta ao 'luso princípio queer", 2004, p. 236.
} 
arrebatadora, em que as insinuações entre os personagens da narrativa demonstravam a relação afetiva entre pessoas do mesmo sexo. Já naquela época, século XIX, a homocultura encontrava seus caminhos, produzindo e agregandose a outros discursos, inserindo-se na cultura geral e dela criando cultura própria; é dessa forma que podemos entender o motivo pelo qual o túmulo de Oscar Wilde é visitado por homossexuais de todo o mundo, que lá deixam suas marcas de beijos e declarações em batom, pois o escritor é considerado um dos muitos prenunciadores da subjetividade gay.

No ousado romance, percebe-se a presença de afetividade dos personagens em relação ao jovem Dorian, que desperta nos amigos íntimos curiosidade, interesse e paixão, de forma que as insinuações desses sentimentos se efetivem narrativamente por meio dos diálogos. Os indícios de homoafetividade podem ser notados principalmente nos trechos em que Basil, o pintor, fala de seu amigo Dorian para Lord Henry, que também demonstra certo interesse pelo jovem. As relações que ambos os personagens estabelecem com Dorian adquirem configurações diferentes, pois enquanto o primeiro quer preservar a beleza e a candura de Dorian, o segundo pretende despertar no jovem as sensações mais voluptuosas possíveis, seduzindo-o para adotar uma vida prazerosa, sem limites.

O hedonismo, estilo de vida que Lord Henry pregava, toma proporções sedutoras para o jovem Gray, que fica tentado a descobrir as experiências prazerosas que o mundo poderia lhe oferecer, tal qual consta em determinada passagem, quando Lord Henry afirma: “Viva! Viva a maravilhosa vida que em si existe. [...] Procure incessantemente novas sensações. Nada receie... Um novo 
Hedonismo - eis o que o nosso século deseja. Você pode ser o seu sonho visível" ${ }^{28}$. Além desse trecho, há outro em que Dorian é incentivado a ceder a todo tipo de ação, atitudes e práticas condenadas pela moral da sociedade: "Somos punidos pelas nossas recusas. Cada impulso que tentamos estrangular germina no cérebro e envenena-nos. [...] A única maneira de nos vermos livres de uma tentação é ceder-lhe"29.

Lord Henry intenta despertar em Dorian o sentimento aventureiro, boêmio e hedonista de que era defensor, porém não praticante, pois ao ver o jovem, fica encantado com a perfeição de seus traços, com a graciosidade dos modos, com a ternura do olhar e a ingenuidade de sua personalidade. $\mathrm{O}$ encanto de Dorian, ao ser visto pelo Lord, causa-lhe imediatamente impacto: "Lord Henry contemplou-o. Sim, era maravilhosamente gracioso, sem dúvida, com seus lábios vermelhos de fino recorte, com os seus profundos olhos azuis, com seu cabelo loiro encaracolado. [...] Não admirava que Basílio o adorasse"30.

Assim, percebe-se que Dorian, com a [...] "excitante maravilha da sua face $^{\prime 31}$, ao encantar os amigos, desperta neles não apenas sentimentos de admiração, mas de adoração, em que podemos perceber singulares notações de afetividade, que se evidencia no primeiro encontro entre Basil e Dorian:

Rodei um pouco, e, pela primeira vez, dei de olhos com Dorian Gray. Quando os nossos olhares se cruzaram, senti-me empalidecer. Avassaloume uma estranha sensação de terror. Compreendi que estava perante alguém com uma personalidade tão fascinante que, se eu o permitisse,

\footnotetext{
${ }^{28}$ Oscar Wilde, Op. Cit., 1971 (1890), p. 29.

${ }^{29}$ Ibidem, p. 25.

${ }^{30}$ Ibidem, p. 22-23.

${ }^{31}$ Ibidem, p. 41.
} 
absorveria toda a minha individualidade, toda a minha alma, a minha própria arte. $^{32}$

O personagem Basil sente de maneira imediata atração por Dorian quando o vê pela primeira vez. Nesse trecho, fica patente a constituição desse personagem, que não causa apenas apreço, mas também fascínio de proporções arrebatadoras, de forma que Basil, no primeiro contato visual com o jovem, sente intensa emoção, fazendo-o submeter-se plenamente à influência de Dorian. O fato de haver, já neste trecho, ligação de estranhamento e atração que se efetiva entre dois personagens do mesmo sexo, possibilita pensar a respeito de certa subjetividade homossexual presente no romance, que paira em trechos onde a beleza de Dorian é destacada pelo narrador, como na seguinte passagem:

De súbito, encontrei-me face a face com o jovem cuja personalidade me emocionara tão estranhamente. Estávamos muito próximos um do outro, quase nos tocávamos. Os nossos olhos voltaram a encontrar-se. [...] Também ele sentia que estávamos destinados a travarmos conhecimento. ${ }^{33}$

O trecho acima não possibilita apenas pensar sobre certa subjetividade homossexual, mas também numa clara e evidente homoafetividade na troca de olhares, ações e gestos entre os personagens. No romance, após finalmente conhecer o jovem, Basil assume explicitamente o vício que a presença de Dorian lhe desperta. Quando Lord Henry lhe pergunta: “Diga-me mais coisas de Dorian

\footnotetext{
${ }^{32}$ Ibidem, p. 14.

${ }^{33}$ Ibidem, p. 15.
} 
Gray. Vê-lo com muita frequência?", Basil lhe responde: “Todos os dias. Não me sentiria feliz se o não visse todos os dias. Ele é-me absolutamente necessário" ${ }^{34}$.

Essas notações homoafetivas, ao evidenciar a paixão de um homem em relação a outro, possibilitam pensar acerca da homoafetividade já presente na produção literária da época, bem como sobre demais produções artísticas, culturais e sociais oriundas de sujeitos que enunciaram sua sexualidade dissidente e desafiaram a heteronormatividade. Ainda no romance, os sentimentos que Basil diz ter em relação a Dorian adquirem nuances tão significativas que Lord Henry afirma, ao notar a devoção de Basil pelo jovem: “O que me contou é um verdadeiro romance $[\ldots]^{35}$. De fato, romance de proporções também sentimentais e amorosas, a relação que o pintor Basílio Hallward estabelece com Dorian deixa patentes insinuações de afetividade homossexual, caracterizando $O$ Retrato de Dorian Gray como produção que desafia as normas de uma sociedade preconceituosa, sisuda e dogmática, até então fundamentada numa lei que proibia e punia sujeitos que tivessem relações homoafetivas.

Outro trecho significativo deste romance encontra-se já no início, quando Basil, claramente com ciúmes de Dorian com Lord Henry, alega: "Não sei o que Harry lhe esteve a dizer, mas conseguiu que você ficasse com a expressão mais fascinante. Suponho que lhe esteve dizendo galanteios" ${ }^{36}$. Esse diálogo evidencia, também, significativas notações homoculturais no romance, como também no trecho a seguir, em que Basil afirma:

\footnotetext{
${ }^{34}$ Ibidem, p. 17.

${ }^{35}$ Ibidem, p. 20.

${ }^{36}$ Ibidem, p. 26-27.
} 
[...] Não é só por eu o pintar, o desenhar, o esboçar. É claro que fiz tudo isso. Mas ele é para mim muito mais do que um modelo. [...] A presença física deste moço - para mim não passa de um rapazito, embora já tenha mais de vinte anos -, a sua presença física... Ah!, não sei se você consegue compreender tudo o que isto significa! ${ }^{37}$

A paixão inominada de Basil se revela como paixão homossexual conforme a mesma já é nominada de forma subjetiva e indireta. A respeito desse amor inominado, é interessante o fato em que o autor, Oscar Wilde, durante o julgamento, ao se referir à relação entre dois homens, afirma ser esse um "amor que não ousa dizer seu nome", haja vista a condenação e o preconceito imputado aos homossexuais. É relevante a circunstância em que, apesar de afirmar ser um amor que não ousa dizer seu nome, Oscar Wilde, em vida, nominou-o, dando significações legítimas e expressivas à homossexualidade.

\section{Considerações finais}

Considerado um dos mais significativos porta-vozes da causa homossexual, Oscar Wilde colabora com o protagonismo das dissidências sexuais e, portanto, possibilita aprofundar problematizações acerca da homocultura. Pode-se dizer, além disso, que Wilde escreveu um romance subversivo, questionando, criticando a hipocrisia prevalecente em sua época e ironizando os costumes e valores contraditórios da sociedade vitoriana.

Dessa forma, ao pautar as notações homoculturais presentes em $O$ Retrato de Dorian Gray, são efetuados processos a contrapelo da tradição, trazendo à tona

${ }^{37}$ Ibidem, p. 17-18. 
a expressão dos sujeitos que foram violentados, marginalizados, segregados e silenciados por influências hegemônicas, opressoras e excludentes. Assim, por meio da evidenciação histórico-literária das expressões homossexuais, os sujeitos desafiadores da norma heteronormativa adquirem não somente protagonismo e viabilidade lócus-discursiva, mas adquirem, também, possibilidade de reconhecimento e pertença em instâncias culturais e relacionais, dentre as quais a homocultura.

\section{Referências}

ARFUCH, Leonor. O espaço biográfico: dilemas de subjetividade contemporânea. Trad. Paloma Vidal. Rio de Janeiro: EdUERJ, 2010.

BAKHTIN, Mikhail Mikhailovich. Estética da criação verbal. São Paulo: Martins Fontes, 2003.

BILHEIRO, Ivan. Gênio na vida, talentoso na arte: Uma visão da biografia de Oscar Wilde. Grupo de Leituras Sempre um Livro. 2013. Disponível em: https://sempreumlivro.files.wordpress.com/2013/01/uma-visc3a3o-dabiografia-de-oscar-wilde3.pdf. Acesso em: 06 out. 2018.

CAVALHEIRO, Juciane dos Santos. A concepção de autor em Bakhtin, Barthes e Foucault. SIGNUM - Estudos Linguísticos, Londrina, v. 11, n. 2, p. 67-81, dez. 2008.

MAN, Paul de. Autobiografia como Des-figuração. Panfleto político-cultural Sopro. 2012. Disponível em: 
http://www.culturaebarbarie.org/sopro/outros/autobiografia.html. Acesso em: 04 set. 2019.

FOUCAULT, Michel. O triunfo social do prazer sexual: uma conversação com Michel Foucault. In: FOUCAULT, Michel. Ética, sexualidade e política.

Organização e seleção de textos por Manoel Barros da Motta. Trad. Elisa Monteiro; Inês Autran Dourado Barbosa. Rio de Janeiro: Forense Universitária, 2010. p. 119-125.

LUGARINHO, Mário Cesar. Homocultura e literatura: de volta ao "luso princípio queer". In: LOPES, Denilson (Org.). Imagem e Diversidade Sexual - estudos da homocultura. São Paulo: Nojosa, 2004. p. 234-239.

MARTINS, Ferdinando. Cenas Paralelas: Do Arcaico ao Pós-moderno nas Representações do Gay no Teatro Brasileiro Contemporâneo. In: COSTA, Horácio (Org.). Retratos do Brasil Homossexual: Fronteiras, Subjetividades e Desejos. São Paulo: Edusp, 2010. p. 245-256.

PIRES, Eliane Cristine Raab. Oscar Wilde: A tragicidade da vida de um escritor. Portugal: Instituto Politécnico de Bragança, 2005.

QUELUZ, Rebeca Pinheiro; SILVA, Andressa Cristine Marçal da. Oscar Wilde Revisitado: Estudo de Três Adaptações de O Retrato de Dorian Gray. Unioeste: Revista de Literatura, História e Memória, Cascavel, v. 11, n. 17, p. 171-185, 2015.

SCHIFFER, Daniel Salvatore. Oscar Wilde. Trad. Joana Canêdo. Porto Alegre: L\&PM, 2010. 
TOFFOLI, Tânia. O Retrato de Dorian Gray: um romance em três tempos - Circulação entre Inglaterra e Brasil. 2013. 174f. Dissertação (Mestrado em Teoria e História Literária) - Instituto de Estudos da Linguagem, Universidade Estadual de Campinas, Campinas, SP.

WILDE, Oscar. O Retrato de Dorian Gray. Trad. Artur Parreira. Lisboa: Editorial Verbo, 1971 (1890).

\section{Referência para citação deste artigo}

SILVA, Leandro Souza Borges. O amor que não ousa dizer seu nome: notações homoculturais em $O$ Retrato de Dorian Gray, de Oscar Wilde. Revista PHILIA | Filosofia, Literatura \& Arte, Porto Alegre, volume 2, número 1, p. 316 - 340, junho de 2020. 